\title{
Triatomines in dwellings and outbuildings in an endemic area of Chagas disease in northeastern Brazil
}

\author{
Antonio Fernando Rodrigues Lima ${ }^{[1]}$, Veronica de Lourdes Sierpe Jeraldo ${ }^{[1]}$, Maxwell Souza Silveira ${ }^{[2]}$, \\ Rubens Riscala Madi[i[2], Thiago Bicudo Krempel Santana ${ }^{[2]}$ and Cláudia Moura de Melo ${ }^{[1]}$
}

[1]. Laboratório de Doenças Infecciosas e Parasitárias, Instituto de Tecnologia e Pesquisa, Universidade Tiradentes, Aracaju, SE. [2]. Laboratório de Biologia Tropical, Instituto de Tecnologia e Pesquisa, Universidade Tiradentes, Aracaju, SE.

\section{ABSTRACT}

Introduction: The present study identified the triatomines collected in intra and peri-domestic environments, observed the occurrence of Trypanosoma cruzi infection in triatomines and correlated this information with housing conditions and the fauna associated with the rural areas of the City of Itabaianinha, located in the State of Sergipe, Brazil. Methods: Quarterly visits were conducted between March 2009 and March 2010, and the homes to be visited for the active search of insects were determined by random selection. In each housing unit, the insects were collected by a manual search with a metal clip and flashlight to inspect openings and cavities, with a collection time of one hour/home/individual. The Pirisa ${ }^{\circledR}$ dislodge chemical was used to force the insects to leave their ecotopes. Analysis of the intestinal contents of triatomines was performed in the laboratory to establish the presence of Trypanosomatidae. Results: Of the 103 dwellings surveyed, 17.5\% were infested with Panstrongylus megistus. The village of Mutuca exhibited the highest infestation rate (38.1\%). All the villages with relevant infestation rates were situated in the northern area of the city. The highest percentage of vector infection was found in the village of Água Boa (56.5\%). The rural dwellings were found to be primarily brick or wooden house with or without roughcast or plastered walls, and the outbuilding most frequently associated with triatomines was the chicken run. Conclusions: These results emphasise the need for broader vector control and surveillance and for educational campaigns in the context of the Chagas Disease Control Program.

Keywords: Chagas disease. Panstrongylus megistus. Endemic area. Sergipe. Brazil.

\section{INTRODUCTION}

In Brazil, the vector transmission of human Chagas disease is present in all states of the northeastern region ${ }^{1}$, and its occurrence depends primarily on the distribution of domestic vectors ${ }^{2}$. Vector transmission has always been considered to be the most important mode of transmission in Brazil, corresponding to $80 \%$ of cases of parasitic diseases, and is associated with the ability of these triatomines to invade and adapt to homes and outbuildings, especially those of low socioeconomic conditions ${ }^{3,4}$. Carlos Chagas correlated this trypanosomiasis transmission with the presence of triatomines in intra-domestic areas ${ }^{5}$.

Hunger is one of the main factors involved in the spread of these insects to other ecotopes. Consequently, in addition to bird nests, tree hollows, crevices between rocks, fallen trunks, exposed roots, loose tree bark and palm tree and bromeliad leaves, triatomines can also be found in peri- and intra-domestic environments, especially in poorly constructed housing units. Triatomines undergo a domiciliation process when they are forced out of their wild environments due to habitat destruction around dwellings, after which they find shelter in rural constructions $s^{6-8}$.

In addition, the presence of domestic animals and peri-domestic constructions used for animal maintenance and breeding greatly influences the presence and transmission of parasites because they provide a permanent food source and promote contact between vectors and humans ${ }^{7,9-12}$.

Address to: Dra Cláudia Moura de Melo. LDIP/ITP/UNIT. Av. Murilo Dantas 300, 49032-490 Aracaju, SE, Brasil.

Phone: 5579 3218-2230

e-mail: claudiamouramelo@hotmail.com

Received in 11/03/2012

Accepted in 24/05/2012
The northeastern region of Brazil is still predominantly rural and has the highest indices of low-quality human dwellings that are adequate to shelter triatomines. In 1996, the Programa de Controle da Doença de Chagas (PCDCh - Chagas Disease Control Program) of the Fundação Nacional de Saúde/Ministério da Saúde (FNS/MS Brazilian Health Ministry National Health Foundation) collected 290576 triatomines in Brazil, the majority (69.2\%) collected in the northeastern region of the country ${ }^{13}$.

In recent years, northeastern Brazil has been affected by several actions impacting the environment, including native vegetation deforestation, mangrove destruction, desertification and the concentration of coastal estates that, together with certain economic activities such as cattle raising, citrus fruit cultivation, subsistence agriculture and livestock raising, destroy the environment in areas close to where low-income populations live ${ }^{14}$.

The State of Sergipe has been on constant alert since the first reports of Chagas disease in the northeastern region in 1913, followed by serological surveys conducted in schoolchildren aged between 7 and 14 years in the 1970s and 1990s as well as the Health Ministry's publication of the Consenso Brasileiro em Doença de Chagas ${ }^{15}$, which aimed to guide control activities and classified the state as a highrisk area. Anthropic destruction of the environment, such as that associated with citrus fruit plantations and red ceramic exploration, have occurred in Sergipe, especially in the City of Itabaianinha. The lack of areas dedicated to the production of vegetable species used to make fuel in Sergipe has become a serious problem for red ceramic producers due to the destruction of the native vegetation, especially the caatinga (Brazilian xeric shrubland and thorn forest), causing a relevant impact on the environment.

In the last ten years, the City of Itabaianinha alone included more than $50 \%$ of the reported human cases of Chagas disease, and several vector species were found in this location, including Panstrongylus megistus, 
Panstrongylus lutzi, Triatoma tibiamaculata, Triatoma melanocephala and Triatoma pseudomaculata ${ }^{16}$.

The aim of the present study was to identify the triatomines collected in the intra- and peri-domestic environments and to observe the occurrence of Trypanosoma cruzi infection in these insects' digestive tract, correlating this information with the housing conditions and fauna associated with the rural area of Itabaianinha, State of Sergipe, Brazil.

\section{METHODS}

The City of Itabaianinha covers an area of $480.4 \mathrm{~km}^{2}$ and is situated in the south-central area of Sergipe $\left(11^{\circ} 16^{\prime} 26^{\prime} \mathrm{S}\right.$ and $\left.37^{\circ} 47^{\prime} 24^{\prime \prime} \mathrm{W}\right)$, $120 \mathrm{~km}$ from the capital City of Aracaju. The local population is estimated to be 37,431 inhabitants ${ }^{17}$. The city has a typical dry and sub-humid megathermal climate, with an annual mean temperature of $24.2^{\circ} \mathrm{C}$, annual mean rainfall of $976.9 \mathrm{~mm}$ and a rainy season that occurs between March and August.

The city's rural area is divided into 72 villages and includes $55.7 \%$ of the population. Its economy is based on citrus fruit plantations, ceramic production and small and large animal husbandry. The area's natural vegetation is composed of grasslands, shrublands, capoeira (secondary vegetation composed of grasslands and scattered shrubs), caatinga and traces of vegetation ${ }^{18}$.

The present study was conducted with quarterly visits between March 2009 and March 2010, and the housing units sampled were randomly selected from the rural housing units (intra- and peridomestic environments) situated in the villages that were registered with the City of Itabaiaininha's Chagas Disease Control Program.

First, villages with the highest prevalence of Chagas' disease recorded in the control program were selected. Then, a random selection was held to determine which homes would be visited for the active search of insects, thus establishing an average seek time number of 24 housing units per field trip, for a total of 103 housing units analysed.

In each housing unit, insects were collected using the selective method, i.e., manual search with metallic tweezers and a flashlight to inspect openings and dark places, with a collection time of one hour/housing unit/individual. Pirisa ${ }^{\circledR}$ chemical dislodger was used to force insects to leave their resting places. In the housing units where triatomines were found, a transect extending $50 \mathrm{~m}$ in all cardinal directions (north, south, east and west) was established, forming a circle around the house. In the area of the transect, a search based on the selective method in natural environments was conducted (burrows, openings in the ground, bird nests, waste materials and tree trunks, among others).

The triatomines collected were identified using the key of Lent and Wygdzinsky ${ }^{19}$. Insects were dissected, and their last abdominal segments were compressed to obtain faecal material, which was observed under light microscopy (at $400 \mathrm{x}$ magnification) to detect Trypanosomatidae ${ }^{15,20}$. Housing units where the searches and triatomine collections were performed were geo-referenced using a GPS (Global Positioning System) receiver (Etrex-Garmin ${ }^{\circledR}$ ).

The housing units visited were classified according to the type of construction: Type 1, brick house with roughcast walls, sub-floor and floor, ceiling and clay tile or fibre cement roof; Type 2, brick or wooden house with or without roughcast or plastered walls, sub-floor and floor, without a ceiling or clay tile or fibre cement roof; Type 3, wooden, straw or thatch house without a roof or ceiling, or with a roof of zinc, straw or other material ${ }^{21}$. In addition, outbuildings, such as deposits, waste deposits, chicken runs, pigsties and corrals, and the animals associated with outbuildings were observed.

The following entomological indicators were used to analyse the data, as recommended by the Brazilian Health Ministry ${ }^{15}$ :

Dispersion index $(\mathrm{DI})=\frac{\text { number of locations with triatomines } \times 100}{\text { number of locations surveyed }}$

Household infestation index $(H I I)=\frac{\text { number of positive housing units } x 100}{\text { number of housing units surveyed }}$

Natural infection index $(\mathrm{NII})=$ number of triatomines collected

Household triatomine density $(\mathrm{HTD})=\frac{\text { number of triatomine specimens collected } \times 100}{}$ number of housing units surveyed

Pearson's correlation coefficient was obtained to associate the number of triatomines infected with Trypanosomatidae with the variety of animal raised. All analyses were performed with a significance level of $5 \%$.

\section{RESULTS}

In the present study, 103 rural housing units were visited between March 2009 and March 2010, including primary buildings and outbuildings, in the villages of Garangau, Maurício, Carretéis, Mata Verde, Mutuca, Fundão, Antas, Água Boa and Piabas. The dispersion index (DI) was $66.7 \%$ among the nine villages, with triatomines found in both the domestic and peri-domestic areas. Of the 103 housing units analysed, 18 were infested with triatomines ( $\mathrm{HII}=17.5 \%)$, and insect colonies were observed in both the peri- and intra-domestic environments. The village of Mutuca exhibited the highest HII (38.1\%), followed by the villages of Fundão and Antas (25\%) (Table 1).

TABLE 1 - Household infestation index of triatomines of housing units in the villages of rural Itabaianinha, State of Sergipe, Brazil between March 2009 and March 2010.

\begin{tabular}{lcccc}
\hline & \multicolumn{2}{c}{ Housing units } & Household infestation \\
\cline { 2 - 3 } Villages & surveyed & infested & index (\%) \\
\hline Mutuca & 13 & 5 & 38.5 \\
Fundão & 12 & 3 & 25.0 \\
Antas & 11 & 4 & 25.0 \\
Piabas & 13 & 2 & 18.2 \\
Mata Verde & 17 & 2 & 15.4 \\
Água Boa & 9 & 0 & 11.8 \\
Carretéis & 9 & 0 & 0.0 \\
Garangau & 3 & 0 & 0.0 \\
Mauricio & 103 & 18 & 0.0 \\
\hline Total & & 2 & 17.5 \\
\hline
\end{tabular}


The local profile of the rural housing units revealed a very heterogeneous and precarious pattern, with the majority of houses as type 2 (56.3\%), followed by $27.2 \%$ as type 3 and $16.5 \%$ as type 1 . The mean distance of properties to Itabaianinha's urban centre was approximately $11.55 \mathrm{~km}( \pm 2.26$; maximum $=13.81 \mathrm{~km}$ and minimum $=6.54 \mathrm{~km})$, and the mean distance between properties was approximately $4.08 \mathrm{~km}( \pm 2.15$; maximum $=9.63 \mathrm{~km}$ and minimum $=0.66 \mathrm{~km}$ ).

In the peri-domestic areas studied in the City of Itabaianinha, there were corrals, waste deposits and chicken runs, many of which had improvised structures.

Of the 131 triatomine specimens analysed, 41 were positive for Trypanosomatidae, which corresponds to a natural infection index (NII) of $31.3 \%$ (Table 2). All six villages where triatomines were found exhibited natural infection indices; the lowest vector infection percentage was found in Antas (2.9\%), while the highest infection percentage was in Água Boa, where $56.5 \%$ of insects studied had Trypanosomatidae in their intestinal contents.

All triatomine specimens collected belonged to the Panstrongylus megistus species.

With regards to the developmental stage of insects collected, $56.4 \%$ were in the adult stage, whereas $43.6 \%$ were in nymph stages. Associating the developmental stage with the natural infection indices, adult triatomines exhibited the highest rates of infection (63\%), followed by third-stage nymphs (30.8\%) and fifth-stage nymphs (23.8\%) (Table 3). In addition, there were traces of triatomines, such as exuviae, exocoria, faeces and eggs. With regards to sex, the number of females collected was higher than that of males at a ratio of 1.25:1 (F:M) except in September, when the number of males collected was higher.

The colonization index of triatomine $P$. megistus collected in the region appears to be low due to not having nymphs were found inside the home. However, we emphasize the presence of these developmental stages in household near or adjacent to human dwellings, some of which were found positive (Table 3).

The triatomine infestation index in the peri-domestic outbuildings was $31.6 \%$ in chicken runs, followed by corrals (26\%) and waste deposits (21\%) (Table 4).
TABLE 2 - Natural infection index of triatomines for Trypanosoma cruzi in the villages of rural Itabaianinha, State of Sergipe, Brazil between March 2009 and March 2010.

\begin{tabular}{lcccc}
\hline & \multicolumn{3}{c}{ Number of specimens } & Natural infection \\
\cline { 2 - 4 } Village & collected & surveyed & positive & index (\%) \\
\hline Água Boa & 23 & 23 & 13 & 56.5 \\
Mata Verde & 35 & 35 & 19 & 54.3 \\
Piabas & 8 & 7 & 1 & 14.3 \\
Mutuca & 15 & 13 & 3 & 23.1 \\
Fundão & 20 & 18 & 4 & 22.2 \\
Antas & 40 & 35 & 1 & 2.9 \\
Carretéis & 0 & 0 & 0 & 0.0 \\
Garangau & 0 & 0 & 0 & 0.0 \\
Maurício & 0 & 0 & 0 & 0.0 \\
\hline Total & 141 & 131 & 41 & 31.3 \\
\hline
\end{tabular}

TABLE 3 - Distribution of intra and peri-domestic triatomines collected, according to developmental stage and positivity, in the villages of Itabaianinha, State of Sergipe, Brazil between March 2009 and March 2010.

\begin{tabular}{lrrrrr}
\hline & \multicolumn{4}{c}{ Triatomines } \\
\cline { 2 - 3 } \cline { 6 - 7 } Developmental stage & \multicolumn{2}{c}{ collected } & & \multicolumn{2}{c}{ infected } \\
\cline { 2 - 3 } \cline { 6 - 7 } & $\mathbf{n}$ & $\%$ & & $\mathbf{n}$ & $\%$ \\
\hline $1^{\text {st }}$ instar & 6 & 4.3 & & 0.0 & 0.0 \\
$2^{\text {nd }}$ instar & 7 & 4.9 & & 1 & 2.4 \\
$3^{\text {rd }}$ instar & 13 & 9.2 & & 5 & 12.2 \\
$4^{\text {th }}$ instar & 20 & 14.2 & & 1 & 2.4 \\
$5^{\text {th }}$ instar & 21 & 14.9 & & 5 & 12.2 \\
Adults & 74 & 52.5 & & 29 & 70.7 \\
\hline Total & 141 & 100.0 & & 41 & 100.0 \\
\hline
\end{tabular}

During collections, many housing units included breeding domestic animals and other types of animals that can be a food source for triatomines or act as reservoir hosts. Among these animals, chickens (33.1\%), dogs (21.3\%), pigs (12.4\%) and cats (10.7\%) stand out.

In addition, there was a significant correlation between the number of triatomines collected, the number of positive triatomines and the variety of animal present on the property $(p<0.0001 ; r=0.605$ and $r=0.534$, respectively; Figure 1).

TABLE 4 - Household infestation index of peri-domestic outbuildings and natural infestation index of triatomines collected in the outbuildings in the villages of Itabaianinha, State of Sergipe, Brazil between March 2009 and March 2010.

\begin{tabular}{|c|c|c|c|c|c|c|}
\hline \multirow[b]{3}{*}{ Type of outbuilding } & \multicolumn{3}{|c|}{ Household infestation index } & \multicolumn{3}{|c|}{ Natural infestation index } \\
\hline & \multirow{2}{*}{$\begin{array}{l}\text { outbuildings } \\
\text { surveyed }\end{array}$} & \multirow{2}{*}{$\begin{array}{c}\text { outbuildings } \\
\text { infested }\end{array}$} & \multirow{2}{*}{$\begin{array}{l}\text { HII } \\
(\%)\end{array}$} & \multicolumn{2}{|c|}{ number of triatomines } & \multirow{2}{*}{$\begin{array}{l}\text { IIN } \\
(\%) \\
\end{array}$} \\
\hline & & & & surveyed & positive & \\
\hline Chicken run & 42 & 7 & 16.7 & 42 & 12 & 28.6 \\
\hline Corral/barn/stable & 29 & 5 & 17.2 & 29 & 8 & 27.6 \\
\hline Waste deposit & 29 & 4 & 13.8 & 29 & 4 & 13.8 \\
\hline Pigsties & 13 & 1 & 7.7 & 20 & 1 & 5.0 \\
\hline Others & 2 & 0 & 0.0 & 0 & 0 & 0.0 \\
\hline Total & 115 & 17 & 14.8 & 120 & 25 & 20.8 \\
\hline
\end{tabular}

HII: household infestation index; IIN: natural infestation index of triatomines. 


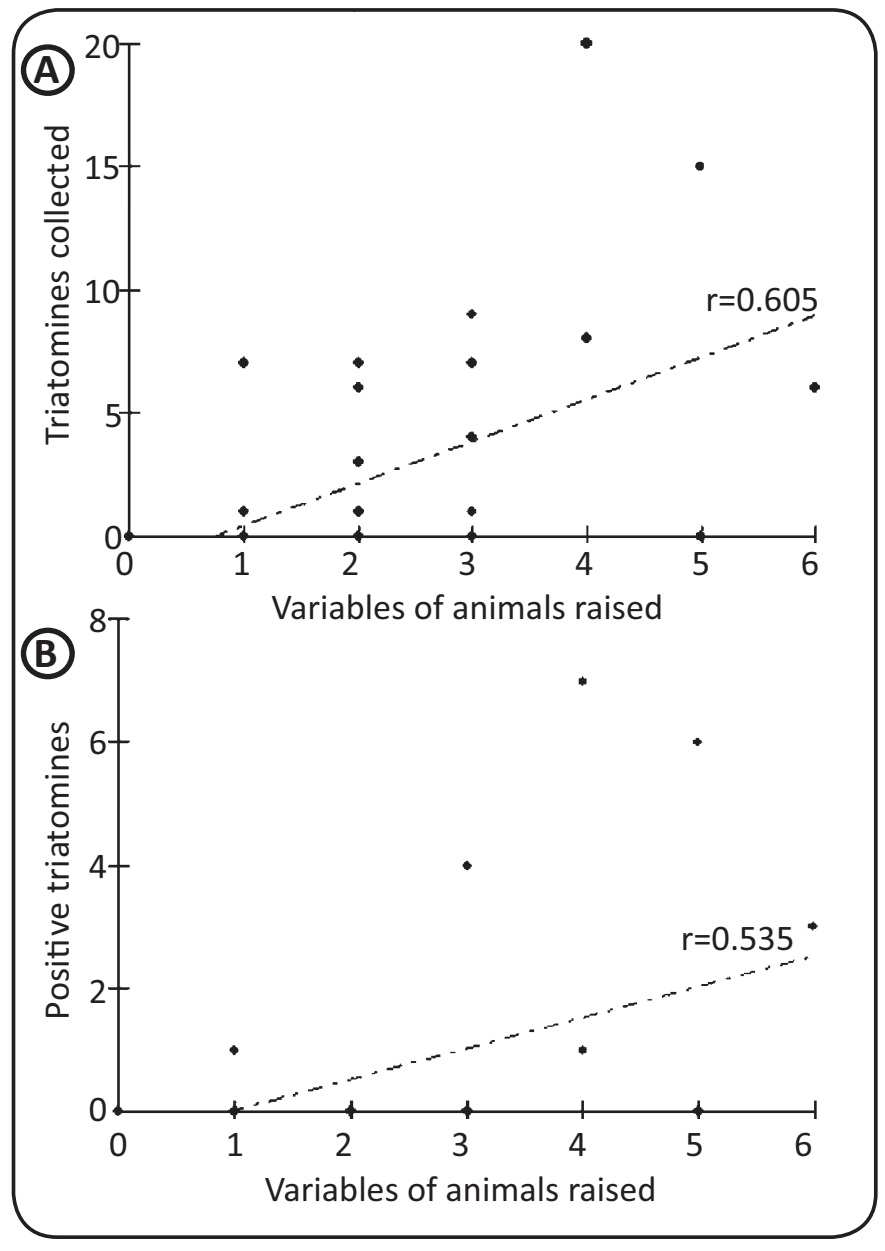

FIGURE 1 - Pearson correlation coefficient graphs between the varieties of animals present on the properties and the number of triatomines collected $(A)$ and the number of positive triatomines (B).

\section{DISCUSSION}

All villages that had a household infestation index were located in northern rural Itabaianinha in an area bordering the Cities of Riachão do Dantas and Tobias Barreto, both of which are in southern central Sergipe. This region includes citrus plantations that cover an area of $71.31 \mathrm{~km}^{2}$, which corresponds to $16.2 \%$ of the total city area ${ }^{18}$. The changes in the natural landscapes made by agricultural systems intensify the triatomine domiciliation trend, especially where herbicide and pesticide use is frequent ${ }^{22}$.

Houses were situated in the middle of pastures and orange plantations and around small secondary forest fragments. The majority of human dwellings surveyed had a highly heterogeneous structure. Sometimes, these housing units were made of bricks; at other times, they were made of wood, with or without plastered or roughcast walls. The construction of the housing units contributed further to the maintenance of the parasitic infection's domestic cycle and reflects the low socioeconomic conditions of the area studied. The area in question has a human development index (HDI) of 0.590, which is lower than the mean value of 0.682 found in the State of Sergipe ${ }^{17}$.

In addition to poor housing quality, rural Itabaianinha residents frequently hang objects such as paintings on the walls, thus providing insects with shelter ${ }^{9,11}$. A study conducted by Villela et al. ${ }^{23}$ investigated what could be done to prevent triatomines from entering houses in rural Bambuí, Minas Gerais (Brazil), a city that has traditionally controlled Chagas disease for more than 50 years. Both adults and children associated anti-triatomine actions with the idea of cleanliness and hygiene, especially by avoiding disorganisation and accumulated objects at home. This reveals a different degree of knowledge of Chagas disease in an area that has been systematically influenced by the Chagas Disease Control Program.

High adult triatomine densities in areas with well-defined dry seasons, such as the State of Sergipe, facilitate insect dispersion to artificial habitats, such as chicken runs and colonisation, especially between October and December for Panstrongylus megistus ${ }^{24}$.

Pigsties, chicken runs and barns were considered to be the main outbuildings colonised by triatomines in the City of Douradoquara, State of Minas Gerais, according to Diotaiuti et al..$^{25}$. Service ${ }^{26}$ argued that the maintenance of corrals around houses provides an adequate habitat for Chagas disease vector populations. Dias ${ }^{27}$ and Dias et al. ${ }^{28}$ reported that such types of peri-domestic outbuildings are used for storage and protection of equipment and tools and create adequate shelter for many insects, which is especially true of triatomines because of their nocturnal habits.

Since the early works of Carlos Chagas, the epidemiological importance of dogs and cats has been emphasised. This is due primarily to the transmission of Trypanosoma cruzi by Triatoma infestans, which also lives in human dwellings ${ }^{29}$. Thus, dogs and cats play an important role in the maintenance of the disease, in addition to other domestic and wild mammals that frequent the areas surrounding homes ${ }^{3,4,12}$. In the case of cats, although infection rates are low, their association with the domestic cycle is closely associated with their wandering habits ${ }^{30}$. Pig and bird breeding was also significant in rural areas and was maintained almost exclusively in the peri-domestic environment. According to Barreto ${ }^{29}$, natural infection of pigs had already been detected in 1940, but their role as domestic reservoir hosts needs to be further studied.

Domestic birds represent an important food source, maintaining triatomine colonies ${ }^{10,30}$. Rossell-Reyes ${ }^{31}$ suggested that chickens are easily detected due to their high body temperature and high surface/volume ratio. In a rural area of the City of Santiago del Estero, Argentina, Wisnivesky-Colli et al. ${ }^{30}$ established that the feeding behaviour of $T$. infestans populations varied depending on the time of the year. These insects fed predominantly on birds exclusively in the warmer months, a fact that could be attributed to egg incubation occurring in the intra-domestic environment.

The results confirm the occurrence of Panstrongylus megistus in rural Itabaianinha, an area where hills predominate and that is located 225 meters above sea level. Infestation (17.5\%) and natural infection indices (31.3\%), in addition to the presence of such vectors in both peri- and intra-domestic areas, reveal their ability to explore the human environment and their potential to transmit Trypanosoma cruzi in the region studied.

In the previous survey conducted by the Chagas Disease Control Program was detected in the region, the presence of Panstrongylus megistus, P. lutzi, Triatoma tibiamaculata, T. melanocephala and T. pseudomaculata ${ }^{16}$. Recent data from 2010 and 2011, triatomine bugs were found in $0.2 \%$ of the 
households examined and $0.8 \%$ of outbuildings were positive for triatomine bugs, not to mention if the triatomine bugs were found infected with Trypanosomatidae ${ }^{32}$. Interestingly, the secretary of health of Sergipe have reported 98 cases in Itabaianinha from 2001 to $2009^{33}$.

Based on the results obtained here, the importance of domestic and livestock animals on the maintenance of vector transmission of Chagas disease can be demonstrated in rural areas primarily comprised of poorly constructed houses, as these animals are associated with the peri-domestic environment.

\section{CONFLICT OF INTEREST}

The authors declare that there is no conflict of interest.

\section{FINANCIAL SUPPORT}

Fundação de Apoio à Pesquisa e à Inovação Tecnológica de Sergipe (FAPITEC-SE)

\section{ABSTRACT IN PORTUGUESE}

\section{Triatomíneos no intra e peridomicílio de área endêmica de doença de Chagas no Nordeste do Brasil}

Introdução: O presente trabalho teve como objetivo identificar os triatomíneos coletados no intra e peridomicílio, assim como verificar a ocorrência de infecção por Trypanosoma cruzi e correlacionar essas informações às condições habitacionais e à fauna associada na zona rural de Itabaianinha, Sergipe, Brasil. Métodos: Visitas trimestrais foram realizadas entre março de 2009 e março de 2010, e as casas visitadas para a busca ativa de insetos foram determinadas por sorteio. Em cada unidade habitacional, os insetos foram capturados por coleta manual com pinça e lanterna para examinar aberturas e cavidades, com um tempo de coleta de uma hora/casa/indivíduo. O desalojador químico Pirisa ${ }^{\circledR}$ foi utilizado para forçar os insetos a abandonar seus ecótopos. A análise do conteúdo intestinal dos triatomíneos foi realizado no laboratório para estabelecer a presença de tripanosomatídeos. Resultados: Em 103 unidades domiciliares examinadas, $17,5 \%$ estavam infestadas por triatomíneos da espécie Panstrongylus megistus. O Povoado Mutuca apresentou a mais elevada taxa de infestação das unidades domiciliares $(38,1 \%)$. Todos os povoados que apresentaram índices de infestação relevantes estavam localizados na região norte do município. A maior percentagem de infecção desse vetor foi observada no Povoado Água Boa (56,5\%). As habitações rurais observadas eram em sua maioria de tijolo ou madeira com as paredes rusticamente rebocadas ou sem reboco, e o anexo frequentemente associado ao triatomíneo foi o galinheiro. Conclusões: Os resultados obtidos ressaltam a necessidade de vigilância e controle vetorial mais abrangentes, bem como de campanhas educativas no contexto do PCDCh.

Palavras-chaves: Doença de Chagas. Panstrongylus megistus. Área endemica. Sergipe. Brasil.

\section{REFERENCES}

1. Ministério da Saúde. Guia de Vigilância Epidemiológica. Caderno 10: Doença de Chagas. 7ạ. Edição. Brasília: Ministério da Saúde; 2010.

2. Vilella MM, Souza JB, Mello VP, Azeredo BVM, Dias JCP. Vigilância entomológica da doença de Chagas na região centro-oeste de Minas Gerais, Brasil, entre os anos de 2000 e 2003. Cad Saude Publica 2005; 21:878-886.

3. Pires HHR, Borges EC, Andrade RE, Lorosa ES, Diotaiuti L. Peridomiciliary infestation with Triatoma sordida Stal, 1859 in the county of Serra do Ramalho, Bahia, Brazil. Mem Inst Oswaldo Cruz 1999; 94:147-149.
4. Souza RCM, Soares AC, Alves LC, Lorosa ES, Pereira MH, Diotaiuti L. Feeding behaviour of Triatoma vitticeps (Reduviidae: Triatominae) in the state of Minas Gerais, Brazil Mem Inst Oswaldo Cruz 2011; 106:16-22.

5. Coutinho M, Dias JCP. A descoberta da doença de Chagas. Cad Cien Tecnol 1999; 16:11-51.

6. Silva IG, Fernandes FF, Silva HHG. Infestação de vetores da tripanossomíase americana no ambiente domiciliar no Estado de Goiás. Rev Patol Trop 1995; 24:41-47.

7. Moreno AR, Carcavallo RU. Enfoque ecológico na epidemiologia da doença de Chagas. In: Carcavallo RU, Girón IG, Jurberg J, Lent H, editors. Atlas dos Vetores da Doença de Chagas nas Américas. Vol. III. Rio de Janeiro: Fundação Oswaldo Cruz; 1999. p. 981-1016.

8. Santos CB, Ferreira AL, Leite GR, Ferreira GEM, Rodrigues AAF, Falqueto A. Peridomiciliary colonies of Triatoma vitticeps (Stal, 1859) (Hemiptera, Reduviidae, Triatominae) infected with Trypanosoma cruzi in rural areas of the state of Espírito Santo, Brazil. Mem Inst Oswaldo Cruz 2005; 100:471-473.

9. World Health Organization (WHO). Control of Chagas` Disease. Tecnical Report Series n 811. Genebra: WHO; 1991.

10. Gajate PP, Bottazzi MV, Pietrokovsky SM, Wisnivesky-Colli C. Relação entre Triatoma infestans, aves domésticas e o homem num povoado de Santiago del Estero, Argentina. Cad Saude Publica 1994; 10:53-57.

11. Andrade ALSS, Zicker F, Oliveira RM, Silva IG, Silva SA, Andrade SS, et al. Evaluation of risk factors for house infestation by Triatoma infestans in Brazil. Am J Trop Med Hyg 1995; 53:443-447.

12. Vilella MM, Rodrigues VLCC, Casanova C, Dias JCP. Análise da fonte alimentar de Panstrongylus megistus (Hemiptera, Reduviidae, Triatominae) e sua atual importância como vetor doTrypanosoma cruzi, no Estado de Minas Gerais. Rev Soc Bras Med Trop 2010; 43:125-128.

13. Dias JCP. O controle da doença de Chagas no Brasil. In: Silveira AC, editor. El control de la enfermedad de Chagas en los países del cono sur de América. Uberaba: Faculdade de Medicina do Triângulo Mineiro; 2002. p. 145-250.

14. Silva RA, Sampaio SMP, Koyanagui PH, Poloni M, Carvalho ME, Rodrigues VLCC. Infestação por triatomíneos em assentamento e reassentamento rurais na Região do Pontal do Paranapanema, Estado de São Paulo. Rev Soc Bras Med Trop 2007; 40:527-532.

15. Ministério da Saúde. Consenso brasileiro em doença de Chagas. Rev Soc Bras Med Trop 2005; 38:1-30.

16. Secretaria Municipal de Saúde. Relatório dos Trabalhos do Programa de Controle de doença de Chagas no município de Itabaianinha 2005-2009. Itabaianinha: Secretaria Municipal de Saúde; 2009.

17. Instituto Brasileiro de Geografia e Estatística (IBGE). Contagem da população 2007. Rio de Janeiro: IBGE; 2007.

18. Secretaria de Estado do Planejamento. Superintendência de Estudos e Pesquisas (SUPES). Anuário Estatístico de Sergipe. Vol. 25; Aracaju: SUPES; 2005.

19. Lent $H$, Wygodzinsky P. Revision of the Triatominae (Hemiptera, Reduviidae) and their significance as vectors of Chagas disease. Bull Am Mus Nat Hist 1979; 163:125-520.

20. Guilherme ALF, Pavanelli GC, Silva SV, Costa AL, Araújo SM. Secondary triatomine species in dwellings and other nearby structures in municipalities under epidemiological surveillance in the state of Paraná, Brazil. Rev Panam Salud Publica 2001; 9:385-392.

21. Macedo HS, Marçal Junior O. Distribuição de vetores da doença de Chagas em nível domiciliar: Um estado na Zona Rural de Uberlândia-MG. Cam Geogr 2004; 3:50-66.

22. Abrahan LC, Gorla DE, Catalá SS. Dispersal of Triatoma infestans and other Triatominae species in the arid Chaco of Argentina - Flying, walking or passive carriage? The importance of walking females. Mem Inst Oswaldo Cruz 2011; 106:232-239.

23. Villela MM, Pimenta DN, Lamounier PA, Dias JCPD. Avaliação de conhecimentos e práticas que adultos e crianças têm acerca da doença de Chagas e seus vetores em região endêmica de Minas Gerais, Brasil. Cad Saude Publ 2009; 25:1701-1710.

24. Forattini OP, Rabello EX, Castanho MLS, Pattoli DGB. Aspectos ecológicos da tripanossomose americana. I - Observações sobre Panstrongylus megistus e suas 
relações com focos naturais da infecção, em área urbana da cidade de São Paulo, Brasil. Rev Saude Publ 1970; 4:19-30.

25. Diotaiuti L, Carneiro M, Loiola CCP, Silveira Neto HV, Coutinho RM, Dias JCP. Alternativas de controle do Triatoma sordida no Triângulo Mineiro; I. Borrifaçäo parcial: intradomicílio no Município de Douradoquara, MG, Brasil. Rev Soc Bras Med Trop 1988; 21:199-203.

26. Service MW. Agricultural development and arthropod-borne diseases: a review. Rev Saude Publ 1991; 25:165-178.

27. Dias ICP. Perspectivas para o controle da doença de Chagas em áreas endêmicas com inseticidas de ação residual. Experiência de Bambuí, Minas Gerais. [Thesis]. [Belo Horizonte]: Faculdade de Medicina da Universidade Federal de Minas Gerais; 1974.

28. Dias JCP, Loyola CCP, Brener S. Doença de Chagas em Minas Gerais: Situação atual e perspectivas. Rev Bras Malariol Doenças Trop 1985; 37:7-28.

29. Barreto MP. Estudo sobre os reservatórios e vetores silvestres do Trypanosoma cruzi: primeiro encontro de Triatoma infestans (Hemiptera, Reduviidae) em ecótopos silvestres. Rev Inst Med Trop São Paulo 1963; 5:289-293.
30. Wisnivesky-Colli C, Ruiz AM, Ledesma O, Gürtler RE, Lauricella MA, Salomon DD, et al. Ecologia doméstica de la tripanosomiasis americana: perfil alimentario del Triatoma infestans em una area rural de la provincia de Santiago del Estero, Argentina. Rev Soc Bras Med Trop 1987; 20:31-39.

31. Rossell-Reyes $\mathrm{O}$. A comparison of the feeding performances of Rhodnius prolixus Stal and Rhodnius robustus Larrousse (Hemiptera: Triatominae). [Thesis]. London: University of London; 1984.

32. Secretaria Municipal de Saúde. Relatório dos Trabalhos do Programa de Controle de doença de Chagas no município de Itabaianinha 2010-2011. Itabaianinha: Secretaria Municipal de Saúde; 2011.

33. Secretaria Estadual de Saúde. Sergipe. Coordenação de Vigilância Sanitária. Relatório técnico do Programa de Controle da Doença de Chagas no estado de Sergipe. Aracaju: Secretaria Estadual de Saúde; 2010. 